\title{
Public procurements in roads infrastructure in DRC: legal and parliamentary control of Chinese contracts
}

\author{
Kilomba Sumaili Adolphe*
}

\section{Introduction}

Since its independence on June 30, 1960, the Democratic Republic of Congo (DRC) remains a weak state. It was still among 15 most corrupt countries in the world in 2018 Transparency International said. ${ }^{1}$ Its poor governance still makes it among the 10 most underdeveloped countries in the world. ${ }^{2}$ The aftermath of its independence was negatively impacted by several institutional crisis such as the secessionist crisis in Katanga by Moses KAPENDA Tshombe, several rebellions in the Kasaï, the assassination of his fist prime minister PATRICE EMERY LumumBA, etc. The first republic (1960-1965) is known to having been a republic of political instability with two main stakeholders: President JosePh Kasavubu and Prime Minister Patrice Emery Lumumba. Conflict of political ambitions undermined any development agenda. Few public infrastructures left by the colonial empire could not be either maintained or improved due to political unrest. To bring back stability, Colonel JosEPHDÉsiré Mobutu made a military coup and became the second President of this country on November 24, 1965. He then stayed on power from November 24, 1965 to May 17, 1997. Throughout his reign, the condition of public infrastructure further worsened. Transparency in the management of public affairs also gained infamy. The political transition from May 17, 1997 to 2006 with successively President Laurent-Désiré Kabila and Joseph Kabila KABANGE had not done better. Accountability and transparency in the management of public affairs remained as low as they were in the early 1960s.

This paper will scrutinize the sector of public procurements in infrastructures projects to gauge good governance and transparency in public affairs. The paper will focus more on road infrastructures than the others with a particular attention on what is known as Chinese contracts. Preference to road is made because more than $3,500 \mathrm{~km}$ of road should have been built from 2007 to date according to the Chinese contracts. The first Congolese public

* Prof. Dr. Adolphe Kilomba Sumaili holds a PhD in international law from the Vrije Universiteit Brussel. He also holds a MA in peace and conflicts studies from the UN Mandated University for Peace (Costa Rica). He teaches law at the Institut Supérieur des Techniques Médicales in Bukavu (ISTM-Bukavu). He is also the National Director of the Congolese Center of Transitional Justice, an independent think tank on transitional justice in DRC (kilombaadolphe@yahoo.fr)

1 See Transparency International, Sub-Saharan Africa: undemocratic regimes undermine anti-corruption efforts, available at https://www.transparency.org/news/feature/cpi2018-subsaharan-africa-regi onal-analysis_accessed on March 21, 2019.

2 UNCTAD, The least developed countries report 2018. Entrepreneurship for structural transformation: beyond business as usual, New York and Geneva, 2018, available at https://unctad.org/en/Publ icationsLibrary/ldcr2018_en.pdf accessed on March 15, 2019. 
procurements law dates back to 1959 on the power of the commander in chief of the national army in procurements ${ }^{3}$ followed by another in 1965 as it will be explained afterwards in this paper. The legislative order $\mathrm{n}^{\circ} 69-054$ of December 5, 1969 abrogated the two previous decrees. This new laws was enacted to organize public procurement in the purpose of improving development and transparency.

Entirely geared to enlighten how public procurements in infrastructures projects are managed and controlled, this paper will successively scrutinize the Congolese legal regime of public procurements (2); explain legal procedures to control public procurement and its practice (3); comment the parliamentary control of the relevant minister (4); comments the con compliance with the law of the Chinese contracts (5) and finally formulate some recommendations as the way forward (6).

\section{The Congolese legal regime of public procurement in infrastructures}

As stated earlier, the first law on public procurements in DRC dates back to 1959 followed by another decree enacted in 1965. In fact, public procurements were regulated by two scattered decrees: one of 1959 granting power in procurements to the commander in chief of the national army and the decree of 1965 on public procurements. The legislative order $n$ ${ }^{\circ} 69-054$ of December 5, 1969 alongside its implementing measures was enacted to improve transparency and governance of public projects. Hence, this legislative order ruled Congolese public procurements for 41 years (1969-2010) before being replaced by a new law enacted in 2010: law n ${ }^{\circ} 10 / 010$ of April 10, 2010. ${ }^{4}$ The following grievances were made to this law: the inadequacy of public procurement procedures that were disseminated in various legal and regulatory texts, obsolete and / or diffuse, with contradictions subject to misinterpretation; the absence of standard documents; the fragility of institutional arrangements to ensure the credibility of public procurements management; the awarding of public procurement according to the former law that was not matching anymore the OECD standard; the absence of a regulatory body for public procurements; the lack of transparency in most structures in the programming, the publication of tenders, contract awards, contract management, and completion reports, essentially in terms of works contracts as well as the absence of recourse and control mechanisms.

This legislative shift was made to update and enhance transparency and accountability the management of public procurements. In the statement of reasons (exposé des motifs), the Congolese legislator rises the obsolescence of the 1969 legislative order. This new law is seen to be a remedy to the inefficiency of the 1969 legislative order. In fact, law nº/010

3 Article 8 of the Congolese public procurement legislative order of 1969, available at http://www.leg anet.cd/Legislation/Droit\%20administratif/Urbanismevoiries/Div/OL.69.054.5.12.1969.htm accessed on March 16, 2019.

4 See law n ${ }^{\circ} 10 / 010$ of April 10, 2010 on public procurement, Kinshasa, Journal Officiel, Numéro Spécial, 30 Avril 2010, available at https://www.leganet.cd/Legislation/JO/2010/JOS. 30.4.2010.pdf accessed on March 15, 2019. 
of April 10, 2010 issued new fundamental rules to match the OECD standard on public procurements. Those new rules provide new procedures of preparation of public projects, the awarding of public contracts and their execution as well as control. The current Congolese law on public procurements is based on the principles of freedom of access to public procurement, the preference of national expertise and competences to international expertise, the equal treatment of candidates, the compliance with the rules of ethics and transparency in the procedures relating thereto.

Another innovation introduced by the 2010 law is the separation of public organs in charge of public procurement. The body in charge of preparation and awarding of projects is now separated from the one in charge of control and none of them can cumulate the function of the other. Cases of awarding public contracts on over-the-counter (OTC) procedures are henceforth very limited. ${ }^{5}$ OTC procedures are now the exception to the general rule that makes mandatory the issuing of call to tenders. As a reminder, a public contract is called an OTC contract when it is awarded without any call to tenders with the authorization of the public service in charge of controlling public procurements. ${ }^{6}$ The request to use OTC procedure must then provide all reasons behind it. The article 7 of the 2010 law defines four types of public procurements: "works contracts; 2 . supply contracts; 3 . service contracts; 4. intellectual services contracts." 0 n the other hand, the article 8 provides that "the purpose of works contracts is to carry out, for the benefit of a contracting authority, all building or civil engineering works or the repair of works of any kind." ${ }^{8}$ We provide the definition of works contracts since this paper deal with them.

The 2010 Congolese law on public procurements has brought in numerous innovations. The Congolese legislator has theoretically proven his determination to increase transparency and accountability in the management of public affairs even though the practice is yet to follow. In Congolese ways of managing public affairs, the beauty of the law remains always far from the reality. One would then ask the raison d'être of legal shifts and reforms in this country! Usually, laws are elegantly designed and drafted while the practice will desperately follow. Examining the 2010 law from an air-conditioned office would award the qualification of a well governed state to the DRC. Yet, the practice does not follow. OTC procedures remain the common way of awarding public procurements at the expense of call to tenders and transparent legal procedures. To divert criticisms, Congolese decision-makers issue calls to tenders to recruit the needed provider of the expected service: "we issue the call to tenders to avoid criticisms. In doing so, nobody will say that we do not comply with the law. It is for the form and no for the substance" states a worker at the Public Procure-

5 See article 42 of the 2010 Congolese law on public procurement.

6 See article 41 of the 2010 Congolese law on public procurement.

7 See article 7 of the 2010 Congolese law on public procurement.

8 See article 8 of the 2010 Congolese law on public procurement. 
ment Regulatory Authority (PPRA) in Kinshasa. ${ }^{9}$ Instead of pursuing the process as outlined by the 2010 law on public procurements, the process usually ends up by awarding the contract to an unexpected provider. Throughout the process, political interference and bribery become the governing principles in this country. Public procurements are awarded depending on political affiliation to the ruling political parties and on closeness with decisionmakers.

\section{Legal control of the ministry in charge of public procurements in infrastructures}

According to the Congolese public procurements law, public procurements are meant to undergo double control upstream and downstream. In fact, there are two types of legal control for public procurements: the ex-ante control and the posterior control with three approving authorities. Talking about road infrastructures, it is worth mentioning that the Ministry in charge of public procurements in road infrastructures is the ministry of infrastructures and public works. The 2010 public procurements law foresees the ex-ante control of any public procurement regardless of ministries. At article 13, paragraph 2, the 2010 public procurements law provides that the organ in charge of the ex-ante control of public procurements is an organ of the ministry of the budget. Its mission concerns "the compliance by contracting authorities with procurement and public service delegation procedures. This check is carried out by non-objection notices, authorizations and necessary derogations." 10 While the aforementioned law does not quote the name of the organ to carry out such a mission, the decree $n^{\circ} 10 / 22$ of April 10, 2010 enacting the manual of procedures of the law of public procurements brought needed precision thereto. The article 14 of that decree provides that the organ in charge of the ex-ante control is the General Directorate of controlling public procurements (GDCPP), an organ of the ministry of budget. On the other hand, the article 21 of the manual of procedures on public procurements also provides exhaustively the list of approving authorities in public procurements: the Prime Minister for all contracts concluded after international tenders and contracts concluded by the Minister having the budget in his attributions; the minister with the budget in his attributions, for the contracts concluded at the end of the national calls for tenders; the supervisory ministers for the contracts concluded by the companies and public establishments, at the end of the national invitations to tender."

About the posterior control, let us say that the posterior control is meant to be carried out by three bodies according to article 6 of the 2010 public procurements law: the contracting authority, the public procurement regulatory authority, any other competent administra-

9 Interview with a worker at the Public Procurement Regulatory Authority (PPRA) in Kinshasa on 15 January 2019.

10 Article 13 of the 2010 Congolese law on public procurements: "Le contrôle a priori, assuré par un service relevant du ministère ayant le budget dans ses attributions, porte sur le respect par les autorités contractantes des procédures de passation des marchés et de délégations de service public. Ce contrôle s'effectue par des avis de non objection, des autorisations et dérogations nécessaires." 
tive body provided for by the laws and regulations in force. Although they are three bodies, the main body in charge of legal control is the public procurement regulatory authority (PPRA) known by its French acronym autorité de régulation des marches publics (ARMP). This body has been created by the decree $n^{\circ} 10 / 21$ of June 2, 2010 of the Congolese Prime minister. By another decree $n^{\circ} 10 / 22$ of June 2, 2010, the Prime minister issued the public procurement procedures manual. ${ }^{11}$ The article 4 of the aforementioned decree details all the missions endowed to the PPRA. It provides at its third paragraph that the PPRA is the body in charge of examining and reviewing any appeal over any dispute that emerges from a public procurement contract. In other words, the PPRA is a non-judicial body of disputes settlement related to public procurements. The paragraph 4 of the same provision considers the PPRA as a body in charge of promoting ethics and proscribing corruption in public procurements.

The paragraph 5 of the article 4 of the aforementioned decree provides that the PPRA has the power of doing post-clearance control (posterior control): "by means of independent audits, carry out post-clearance audits of public procurement procedures and public service delegations and, where appropriate, impose sanctions on proven violations of the relevant regulations." In other words, after fact-checking, the PPRA might impose sanctions where appropriate. The sixth paragraph adds: "carry out periodic monitoring and evaluation missions taking into account the performance indicators for the awarding, control and execution of public contracts and public service delegations." As it is common in the Congolese manners of managing public affairs, practices always make longer to follow the law. While the website of the Congolese PPRA ${ }^{12}$ is full of calls to tenders spread across the country, it remains difficult to find out reports of the whole process from the preparation to the postclearance control. To make its activities much more visible and credible, the PPRA should undertake availing its evaluation reports to the public.

Being a body of post-clearance control (posterior control) and a public organ to fight corruption in public procurements, the PPRA should spread its activities across the Congolese national territory and avail its service. To date, almost provinces are yet to be provided by the representative office of the PPRA. The functioning system remains centralized in Kinshasa. Consequently, the PPRA's services are unreachable by people leaving in the countryside. Moreover, the PPRA's activities and missions are to date unknown by many people as it is for other public bodies like the mining cadaster, the national agency for investment, the forest cadaster, etc. We interrogated 100 people in Bukavu town. All of them were unaware of the existence of the PPRA. Unknown as many other public bodies in charge of increasing transparency, awareness and accountability in public procurements, the PPRA has to strive to enlarge its audience and sensitize people to cooperate with it. While the country remains among the 15 most corrupt countries in the world, judiciary landmark decisions are unfindable over corruption. The judiciary that would strive alongside the

11 See decree $n^{\circ} 10 / 21$ and decree $n^{\circ} 10 / 22$ of June 2, 2010, Kinshasa, Journal Officiel, 2010.

12 See PPRA website: http://www.armp-rdc.org/index.php/fr/travaux accessed on March 15, 2019. 
PPRA against corruption in public procurements is currently allocated $0.6 \%$ of the overall budget. The gap between rules and practice is still huge and efforts to fill it up remain insignificant thus far.

Being a non-judicial body to settle litigations emerging from public procurements contracts, the PPRA is yet to prove its effectiveness in bringing to light all irregularities that affect the public procurement process. To reach such an objective, the PPRA should avail all its reports online to facilitate research on its daily works and advocacies by the civil society. In not availing online its reports, the Congolese PPRA fails to convince Congolese people on its willingness to bring much more transparency in this field infected by corruption and bribery. On the other, financial resources allocated to PPRA are also unknown. In increasing its budget, the Congolese government would demonstrating its real political will to fight corruption in public affairs.

Still on the posterior legal control, it is worth mentioning that any claim over public procurement has to be contested at the contracting authority according to article 73 of the 2010 Congolese public procurement law. The decision of the contracting authority can be challenged at the PPRA. In fact, the PPRA plays the role of an appeal body in settling disputes emerging form public procurement attribution. It is likewise for the public procurements implementation. The Congolese law distinguishes two types of litigation in public procurements. The attribution litigation and the implementation litigation. In either cases, the PPRA plays the role of the appeal body since the first complaint has to be lodged before the contracting authority. It is only in the case of failure of the PPRA that legal action can be taken to the judiciary. Accessing archives of the PPRA would be a great opportunity to review the history of its disputes settlement process. This would also be an occasion to understand and scrutinize the fairness of the PPRA procedures.

\section{Parliamentary control of the ministry in charge of public procurements in infrastructures}

Being a decentralized state, the DRC has a national parliament where all 26 provinces are represented and provincial parliaments. Each of them is endowed by a mission of control of public affairs. In this paper, we will reflect on the role of the national parliament because there were not enough financial means to investigate on provincial parliamentary control of public procurements in road infrastructures. To control the ministry of infrastructures and public works because it is the one in charge of public procurements in roads infrastructures, there is the commission of development of territory and infrastructures (CDTI) at the national parliament. This commission has the mission of controlling public procurements in infrastructures projects across the national territory. After investigating works in roads infrastructures, the CDTI submit its report to the plenary of the national assembly which in turn will decide on what to do next.

The parliament has two possibilities of controlling Government actions on public procurements: either through oral question with recommendations or motion of no confidence 
against the minister in charge of infrastructures and public works. From 2006 to 2019, there has not been thus far a motion of no confidence that has overthrown a minister in charge of infrastructures and public works. Does that mean that all public procurements in roads infrastructures are in compliance with the law? The answer is absolutely negative. In contrary, oral questions have been numerous with a lot of recommendations without any follow-up. The most known case of public procurement fraud is the Chinese contracts as the paper will detail afterwards. The awarding of the biggest public procurements to Chinese enterprises with the funding of EXIM BANK of China triggered debates over the parliamentary control of public procurements in DRC. Explaining the content of Chinese contracts, the former Minister of Infrastructures and public works Pierre LumBI, stated that "the Government has only the duty to inform the parliament over such an agreement according to article 213, paragraph 2 of the Congolese Constitution. It does not need any ratification by the parliament since Chinese contracts were not a treaty." 13 Let us explain shortly Chinese contracts before examining the controversy around it over the parliamentary control which in fact can be either ex-ante or posterior control.

\subsection{Chinese contracts, the landmark public procurement fraud in DRC}

The landmark case of public procurement fraud is what is called in the Congolese parlance "the Chinese contracts" signed on September 7, 2007 between a group of Chinese enterprises (Sinohydro and China Railway Engineering Corporation, CREC in acronym) with the funding of EXIM BANK of China and the Congolese government. To sustain its skyrocketing growth, China's enterprises have been awarded numerous public procurements to build road infrastructures. The Chinese contract was in 2007 "the largest contract ever signed in Africa between the Chinese and the government of the DRC in September 2007." 14 In fact, "they[China]struck a 8.5 billion dollar deal, as big as the total principal debt accumulated during the Mobutu era, according to which China will lend money to construct roads and other important infrastructures in exchange for equity in joint ventures and guaranteed quantity of copper, cobalt, gold and other minerals." 15

In a nutshell, the group of Chinese enterprises took the commitment to build 3,500 Km of roads, 3,500 Km of railways, rehabilitate Kinshasa urban road network, 31 hospitals with

13 Statement of former Minister of Infrastructures and public works, Pierre Lumbi, before the Congolese National Assembly on May 14, 2008 in Kinshasa, available at http://www.congoforum.be/f r/nieuwsdetail.asp?subitem=1\&newsid=143050\&Actualiteit=selected accessed on March 16, 2019.

14 See Stefaan Marysse et Sara Geenen, «Les contrats chinois en RDC : L'impérialisme rouge en marche? » L'Afrique des Grands Lacs. Annuaire 2007-2008, pp287-available at http://congomines. org/system/attachments/assets/000/001/277/original/Les_contrats_chinois_en_RDC.pdf?15023630 83 accessed on March 15, 2019.

15 Ibidem. 
the capacity of 150 beds in each province and 145 health centers. ${ }^{16}$ By the way, Chinese contracts were significantly modified and reduced following the pressure of Bretton Wood institutions (IMF and WB) in exchange with the reaching by the DRC of the completion point of the heavily indebted power countries initiative (HIPC) of the IMF and World Bank. ${ }^{17}$ These public procurements were meant to be funded by EXIM BANK of China at the height of 6.5 billion of US dollars. The Chinese contract generated anxiety at the side of Bretton Wood institutions. The IMF and the World Bank worried over the increase of corruption since China does not rely its cooperation on the prerequisites of good governance and human rights. ${ }^{18}$ This Chinese policy stance is called no strings attached policy. Apart from Bretton woods criticism that led to the revision of the deal as said earlier, the whole Congolese policy-makers were keen to learn and understand the up and downs of this century deal.

Far away from describing all provisions of the Congolese-Chinese deal and its impact on the growth of the DRC, let us focus instead on the awarding process. The Chinese-Congolese public procurement was opaque and the context of its negotiations remains thus far vague. Although it was signed in 2007, three years before the coming into force of the 2010 public procurement law, it remains clear that these public procurements did not even comply with the 1969 legislative order on public procurements. The Government did not even issue a call to tenders as the 1969 legislative order obliges. The implementation phase appeared to be a surprise by the Congolese people: "we are seeing Chinese everywhere. We do not understand why they are in Congo and how they have been awarded public procurements in building infrastructures." 19

\subsection{Controversy of the parliamentary control of Chinese contracts}

While responding to voluminous questions raised by the members of the parliament, PIERRE LUMBI finally confessed some serious weaknesses of Chinese contracts: "many unclear, risky and unlikely commitments; the financing to be mobilized is not quantified; lack of roadmap with stages of implementation; periods of implementation are referred instead of years; Chinese companies win everything while their contribution is low. [Finally, Chinese

16 Ibidem.

17 See Vigilance RDC, La RDC conclut avec le FMI...récale les contrats chinois, available at http://v igilancerdc.afrikblog.com/archives/2009/04/02/13230843.html accessed on March 21, 2019. See also Pettifor, A. (2000) "Debt Cancellation, Lender Responsibility \& Poor Country Empowerment", Review of African Political Economy, Vol.27, No.83, pp.138-144; IMFWB (2006b) Heavily Indebted Poor Countries (HIPC) Initiative - List of Ring Fenced Countries that meet the Income and Indebtedness Criteria at end-2004, International Monetary Fund and International Development Association, Washington DC, April 11.

18 See statement of the chief of the Africa Department of the IMF, Brian AmEs, during a press conference in December 2007, available at http://www.congo-actualites.net/spip.php?article1614 accessed on March 15, 2019.

19 Statement of a human rights activist in Bukavu,March 15, 2019. 
contracts] devote a debt of 10 billion endorsed by reserves of 90 billion."20 Those weaknesses evidence the noncompliance of the Congolese Government with procedures and rules of the Congolese 1969 public procurement law.

The main question of the controversy on the Chinese contracts was whether the Minister of Infrastructures and public works was legally habilitated to sign such contracts on behalf of the country. To this question, PIERre LumBI said that he was mandated by the Government to sign such an agreement. ${ }^{21} \mathrm{He}$ added "the Prime minister has the power to charge a minister with a specific mission on the behalf of the Congolese Government." 22 Several members of opposition wondered why the Government mandated the Minister instead of leaving GECAMINES, the biggest mining company state owned and that enjoys a legal personality, to sign the aforementioned contract. Since Chinese contracts were not state to state contracts, why the Congolese Government did not let GECAMINES signing it alone? In other words, the opposition was reporting the opacity of the whole signing process. The opposition also accused the Government for having substituted itself to GECAMINES. PIERRE LuMBi added that the Government has the tutelage over all state owned firms. It would therefore substitute them where it requested.

We think that such an argument was not convincing because GECAMINES, an autonomous entity enjoying legal personality, could also negotiate such a contract by itself with Chinese firms without any help of the Congolese government. The active involvement of Minister Pierre Lumbi, a former close friend of President Joseph Kabila Kabange, and later on special security adviser of the President, shaded doubt on the transparency of the process that awarded this big public procurement. Another element that evidences the lack of transparency of the Chinese contract is the unavailability of the implementation report. To date, nobody knows, except some Congolese officials, how the Chinese contracts were implemented and what were their results and how they have been modified. Although the Congolese public procurements law came into force in 2010 replacing the former law of 1969 , it worth mentioning that the abrogated law also required a public invitation to tenders to award a public procurement. Even if the 1969 legislative order was not as demanding as the new law is, it listed some requirements to award a public procurement that the Chinese contracts did not comply with. This is the case of issuing a public call to tender ${ }^{23}$ and the duty to comply with forms required by the President of the Republic. ${ }^{24}$ The lack of post-

20 Statement of former Minister of Infrastructures and public works, Pierre Lumbi, before the Congolese National Assembly on May 14, 2008 in Kinshasa, available at http://www.congoforum.be/f r/nieuwsdetail.asp?subitem=1\&newsid=143050\&Actualiteit=selected accessed on March 18, 2019.

21 Ibidem.

22 Ibidem.

23 Article 2 of the Congolese public procurement legislative order of 1969, available at http://www.le ganet.cd/Legislation/Droit\%20administratif/Urbanismevoiries/Div/OL.69.054.5.12.1969.htm accessed on March 16, 2019.

24 Ibidem. 
clearance (posterior control) report of Chinese contracts makes any fact-checking operation difficult to date. The debate over the Chinese contracts ended up with a serial of recommendations.

In sum, the parliament control of public procurement is possible either through an oral question to the minister in charge of the questioned project or through a motion of no confidence in case of unconvincing explanations. It can either ex-ante or posterior. The mission of controlling public procurements in infrastructures is devoted to the commission of development of territory and infrastructures (CDTI) of the Congolese national assembly. Even when explanations are effectively unconvincing as those provided by PIERRE LUMBI, the vote of the motion at the majority is harder because the ruling party serves as a shield for the minister. Public procurements in infrastructures remains a domain of corruption, bribery and felony in DRC. The level of transparency remains as low as it was before the new law. To show its real political will in delivering a ruthless struggle against corruption and lack of transparency in public contracts, the Government should increase the influence of the GDCPP (ex-ante control) and the PPRA (posterior control) and punish policy-makers who keep interfering in its mission. Moreover, the Government should comply with law that provides nullity to all public procurements that do not comply with rules in the matter. In doing so, the Government will be raising awareness and transparency in public affairs. Transparency and accountability in public procurements would also be assuring the quality of works and services to be delivered by the contracting firm.

\section{The lack of effectiveness of the $\mathbf{2 0 1 0}$ public procurements law}

During the assessment workshop organized by the PPRA in Kinshasa in July 8, 2018, it was mentioned that Congolese policy-makers were not respecting rules governing public procurement. ${ }^{25}$ Luzolo Bambi Lesa, the former special adviser of President JosepH Kabila in charge of good governance and the struggle against corruption stated that "OTC procurements promotes corruption in DRC." $26 \mathrm{He}$ added that "public procurements expenditures represent $60 \%$ of the overall Congolese national budget. Yet, from 2010 to 2015, the index of OTC public procurements hits $42 \%$." ${ }^{27}$ This makes at stake the credibility of the Congolese national budget. It is therefore urgent to undertake systematic control of public procurements he concluded. ${ }^{28}$ In spite of being demanding and matching the OECD standard of public procurements, the 2010 public procurement law still suffers from lack of effec-

25 ZoomEco, RDC: le système de passation des marchés publics en cours d'évaluation, July 6, 2018, available at https://zoom-eco.net/secteur-public/rdc-le-systeme-de-passation-des-marches-publicsen-cours-devaluation/ accessed on March 16, 2019.

26 Statement of Luzolo Bambi Lesa on May 25, 2017, available at https://zoom-eco.net/finance/rdc-la -passation-des-marches-de-gre-a-gre-favorise-la-corruption/ accessed on March 16, 2019

27 See Statement of Luzolo BAmBi LeSA on May 25, 2017, available at https://zoom-eco.net/finance/r dc-la-passation-des-marches-de-gre-a-gre-favorise-la-corruption/ accessed on March 16, 2019.

28 Ibidem. 
tiveness. ${ }^{29}$ There are still numerous bottlenecks to increase its effectiveness experts of PPRA said in July 2018. ${ }^{30}$

Three causes have been identified to explain its lack of effectiveness: a significant proportion of public procurements are still awarded according to derogatory procedures (OTC) and, consequently, are not controlled by the General Directorate of Public Contracts Control (DGCMP), an organ of PPRA; the PPRA and its organ of control do not have necessary and sufficient financial capacity to carry out their missions; last and not least, one of the greatest threats to the effectiveness of public procurement reforms remains the resistance to change by state officials and private sector managers who see these reforms as a threat. In other words, this reform represents a loss of money, influence and power for some corrupt state officials. ${ }^{31}$ These three factors still slow down the expected improvement since 2010. The non-respect of public procurements law explains "the fact that the implementation rate of the overall budget decreased from 56\% in 2013 to $51 \%$ in 2014 , and respectively from $36 \%$ to $31 \%$ in the social and infrastructure sectors." 32

The following three OECD templates resumes the risks of bribery and corruption that still loom on Congolese public procurements. Let us start by the steps upstream of submission (template $\mathrm{N}^{\circ} 1$ ) before presenting risks during submission (template $\mathrm{N}^{\circ} 2$ ) and finally risks downstream (template $\mathrm{N}^{\circ} 3$ ).

29 See ZoomEco, RDC: la loi sur les marches publics souffre dans sa mise en oeuvre, July 12, 2018, available at https://zoom-eco.net/finance/rdc-la-loi-sur-les-marches-publics-souffre-dans-sa-mise-e n-oeuvre/ accessed on March 16, 2019.

30 Ibidem.

31 Ibidem.

32 Ibidem. 
Template $N^{\circ} 1$ : steps upstream of submission

\begin{tabular}{|c|c|}
\hline $\begin{array}{l}\text { Steps upstream of } \\
\text { submission }\end{array}$ & Identified risks \\
\hline $\begin{array}{l}\text { Needs assessment, } \\
\text { planning and } \\
\text { budgeting }\end{array}$ & $\begin{array}{l}\text { Incorrect assessment of needs, lack of economic argumentation, poor } \\
\text { planning } \\
\text { - Inability to establish a realistic budget, shortfalls in the budget } \\
\text { Public procurement not in line with the decision-making procedure ap- } \\
\text { plied in general investment in the service } \\
\text { - Interference of senior officials in the decision to launch a contract } \\
\text { - Informal approval of the contract }\end{array}$ \\
\hline $\begin{array}{l}\text { Definition of the } \\
\text { required } \\
\text { requirements }\end{array}$ & $\begin{array}{l}\text { Technical definition } \\
\text { - custom definition for a company } \\
\text { too vague or without result requirements } \\
\text { - Selection or award criteria } \\
\text { lack of a clear and objective definition of criteria no criteria established } \\
\text { and announced before the closing of the bid } \\
\text { false tests or false quality assurance certificates }\end{array}$ \\
\hline $\begin{array}{l}\text { Choice of } \\
\text { procedures }\end{array}$ & $\begin{array}{l}\text { - Administrative costs related to the lack of a strategy for the use of non- } \\
\text { competitive procedures for the amount of the contract or the complexity } \\
\text { of the contract } \\
\text { - Abuse of non-competitive procedures under legal exceptions } \\
\text { - The splitting of contracts into contracts of a small amount; } \\
\text { - The abusive invocation of extreme urgency; } \\
\text { - The abusive invocation of other exceptions, by virtue of the technical } \\
\text { nature of exclusive rights, etc.; } \\
\text { - The renewal of existing contracts without control. }\end{array}$ \\
\hline $\begin{array}{l}\text { The calendar of the } \\
\text { offer }\end{array}$ & $\begin{array}{l}\text { - Lack of consistency in the application of the timetable to bidders; where } \\
\text { information is disclosed earlier to a specific tenderer } \\
\text { - Timetable not guaranteeing equal treatment of tenderers }\end{array}$ \\
\hline
\end{tabular}


Template $N^{\circ} 2$ : steps during submission

\begin{tabular}{|c|c|}
\hline During submission & Identified risks \\
\hline Call for tenders & $\begin{array}{l}\text { Lack of uniformity in how supply information is communicated. } \\
\text { - Non publication of the notice of invitation to tender. } \\
\text { - Disclosure of sensitive or non-public information } \\
\text { justified prices or even practices of unlawful price fixing }\end{array}$ \\
\hline Tender & $\begin{array}{l}\text { Conflicts of interest and corruption at: } \\
\text { The evaluation (establishing links with the bidders over the years, perso- } \\
\text { nal benefits such as gifts, additional or accessory employment, lack of } \\
\text { effective application of the double-eye principle, etc.); } \\
\text { - Approval: there is no real separation in the delegation of powers bet- } \\
\text { ween the bodies responsible for the financial aspects, those responsible } \\
\text { for the contractual aspects and those in charge of project matters. } \\
\text { Difficulty of accessing documents related to the procedure. }\end{array}$ \\
\hline
\end{tabular}

Template $N^{\circ}$ 3: steps downstream of submission

\begin{tabular}{|l|l|}
\hline $\begin{array}{l}\text { Steps down Stream } \\
\text { of submission }\end{array}$ & \multicolumn{1}{c|}{ Identified risks } \\
\hline $\begin{array}{l}\text { Contract } \\
\text { management }\end{array}$ & $\begin{array}{l}\text { Absence of follow-up of the company's achievements, notably lack of quali- } \\
\text { ty control and the schedule provided for by the procedure leading to: } \\
\text { - Substantial changes to the stipulations of the contract to allow more time } \\
\text { and higher prices to the tenderer; } \\
\text { - The replacement of products or the performance of works or the provi- } \\
\text { sion of services of a quality inferior to that provided for in the specifica- } \\
\text { tions; }\end{array}$ \\
$\begin{array}{l}\text { The theft of new assets before delivery to the end user or before registra- } \\
\text { tion in the asset register. }\end{array}$ \\
$\begin{array}{l}\text { - Lack of transparency in the selection of subcontractors and partners or } \\
\text { lack of a mechanism guaranteeing their responsibility. }\end{array}$ \\
\hline $\begin{array}{l}\text { Scheduling and } \\
\text { payment }\end{array}$ & $\begin{array}{l}\text { sulting in: } \\
\text { Wrong accounting and misallocation of costs or transfer of costs bet- } \\
\text { ween contracts; } \\
\text { delays in the payment of invoices, postponements of payment to allow a } \\
\text { revision of prices and increase the financial value of the contract; } \\
\text { False invoicing or double invoicing of goods and services not provided } \\
\text { and invoicing of interim payments before the date on which the tenderer } \\
\text { can claim them. }\end{array}$ \\
\hline
\end{tabular}

These templates were filled up by OECD members during its colloquium held in November 2006. The purpose of such an exercise was to do the inventory of good practices for integrity and resistance to corruption in public procurements. Elements within those templates 
portray the public procurement landscape in DRC. The PPRA whose mission is to control and regulate this sector still lack necessary financial and human resources to bring much more transparency and accountability in this vital sector. Additional practices of corruption and bribery in public procurements are listed by Joseph DizaKana in his thesis on public procurements in DRC. ${ }^{33}$

In his first audit report published in August 2013, the PPRA stated that "only 3 out of 33 institutions audited comply with public procurement procedures." 34 Those institutions were the Suprem Court of Justice, the ministry of public health and the ministry of primary and professional teachings. The report noted the office of the prime minister, the ministry of gender and family and the one of town planning and housing among public organs that have not even communicate the contracts files. ${ }^{35}$ The Inspection of National Police, the Bureau Central de Coordination (BCECO), ${ }^{36}$ the Congolaise des hydrocarbures (COHYDRO) were accused of violating seriously the public procurement law. From October 2010 to December 2011, the PPRA audited 255 public procurements that valued 705 million of dollars. It is upsetting to see that the office of the prime minister is among organs that do not respect the law. That does not give the hope of change in this country were public infrastructures are still in poor conditions. No sanctions were taken against the authors and the tenders. No public contract underwent nullity either. Thus, the GDCPP and the PPRA should be financially enhanced to improve their missions of control of public procurements. To facilitate public procurement scholarship, the GDCPP and the PPTA should avail their annual reports on public procurements.

33 See Joseph Dizakana Mobongobi, Les pratiques frauduleuses dans la phase d'attribution des marchés publics, regard sur la loi 10/010 du 27 avril 2010 relative aux marché publics en république démocratique du Congo, thesis, Kinshasa, Institut Supérieur de Commerce, 2014, available at https://www.memoireonline.com/03/17/9697/Les-pratiques-frauduleuses-dans-la-phase-dattributio n-des-marches-publics-regard-sur-la-1.html\#_Toc460951813 accessed on March 16, 2019.

34 See Radio OkapI, Seules 3 institutions sur 33 institutions auditées respectent les procédures des marchés publics, August 16, 2013, available at https://www.radiookapi.net/economie/2013/08/16/r dc-seules-3-de-33-institutions-auditees-respectent-les-procedures-des-marches-publics accessed on Mach 16, 2019.

35 See Radio Okapi, seules 3 institutions sur 33 institutions auditées respectent les procédures des marchés publics, August 16, 2013, available at https://www.radiookapi.net/economie/2013/08/16/r dc-seules-3-de-33-institutions-auditees-respectent-les-procedures-des-marches-publics accessed on Mach 16, 2019

36 BCECO, a state owned body was created in 2001 to implement projects funded by the World Bank and other international donors. BCECO is among public organs that implement a lot of public procurements. Researching on its procedures would be fruitful for the Congolese public procurements scholarship. See https://www.bceco.cd/index.php/2015-12-06-09-49-17/historique accessed on March 16, 2019. 


\section{Conclusions and recommendations}

This article has demonstrated the itinerary of the Congolese law on public procurements from 1959 to 2019. From the decree of 1959 to the decree of 1965, public procurements were poorly organized. This led to the legislative order of 1969 that ruled public procurements for 41 years. Due the obsolescence of this legislative order, the Congolese government enacted a new law in 2010 to match the OECD standard in public procurements. This law creates a regulatory authority and outlines rules to award public procurements. It also mandate the PPRA to control public procurements and playing the role of an appeal body in case the contracting authority fails to solve the dispute. The judiciary is considered by the law to be a downstream body to control public procurements. While the GDCPP is meant to exercise the ex-ante control of public procurements, the PPRA is in charge of doing the posterior control.

On the other hand, the parliament control of public procurements is possible through the Commission of the development of the territory and infrastructures (CDTI). After auditing public procurements in in infrastructures projects, the CDTI has the liability of either asking the oral question to the minister or initiating a motion of no confidence. The parliamentary control can be either ex ante or posterior. However, despite the beauty of the new public procurement law, the practice does not follow and will take longer to follow. There is a serious lack of effectiveness. For its first report, the PPRA noted that "only 3 out of 33 institutions audited comply with public procurement procedures." Is the situation got improved for the last 5 years? Not sure since the PPRA still lack financial and human resources to carry out its mission. It is likewise with for the GDCPP. That is why the following suggestions should be taken as priority by the Congolese government to improve governance, fight corruption and raise awareness in public procurements: increasing transparency in the recruitment process; promoting accountability in the contracting process in respecting rules in the matter; sensitizing the Congolese community over transparency in public procurements; train civil society to do advocacy for transparency in public procurements; prosecuting all decision-makers violating the public procurements law; publishing report at each stage of the process and systematically nullifying all public contracts awarded without complying with the rules 